\title{
Targeted delivery of immuno-RNase may improve cancer therapy
}

\author{
Miaonan Sun ${ }^{1}$, Liankun Sun ${ }^{1 *}$, Dejun Sun ${ }^{2 *}$, Chunmei Zhang ${ }^{2}$ and Mei Li ${ }^{2}$
}

\begin{abstract}
Background: Immunotoxins are typical therapeutic drugs that can target cancer cells. They exploit the affinity of specific monoclonal antibodies or ligands to cancer cells to deliver a conjugated protein toxin to target sites, thus, attacking the cancer cells.

Methods: The immuno-RNase, Onc-V3, showed the stability of Onc-V3 in the blood stream. Flow cytometry showed that apoptosis occurred in the HO-8910PM cells when treated with Onc-V3. Under the confocal microscope, the green fluorescent, FITC-Onc-V3, were located in the cytoplasm, suggesting that Onc-V3 had a function in the cytoplasm of cancer cells. Moreover, after staining by DAPI, the blue fluorescent nuclei showed shrinkage and grainy. Wound healing assay showed that high concentrations of Onc-V3 inhibited cell migration and the transwell invasion assay showed that Onc-V3 could inhibit cell invasion to the basement membrane. Western blot results showed significantly decreased PARP, procaspase-9, and procaspase-3 in Onc-V3-induced apoptosis.
\end{abstract}

Results: These results of the experiments in vitro had shown that the Onc-V3 could be delivered to the cancer cells accurately and it had strong cytotoxicity on high metastatic cancer cells.

Conclusion: The specific toxicity of Onc-V3 on highly metastatic cancer cells can make it a promising anti-cancer drug by using V3 to target delivery of Onconase.

Keywords: Onconase, Immunotoxin, Apoptosis, Target therapy, Anticancer

\section{Background}

Chemotherapy drugs and radiotherapy have significantly increased the survival rates of tumor-bearing patients and have prolonged their lifetime [1-3]. However, these traditional cancer therapies are based on the rule that cancer cells grow faster than the normal cells thus causing the death of epithelial and hematopoietic stem cells. Therefore, tumor targeting cytotoxic agents present a prospective field of anti-cancer research $[4,5]$.

Immunotoxins consist of a cell-targeting domain and a cytotoxic domain, which are connected directly or through a suitable linker $[6,7]$. The linker is designed to maintain the integrity of the spatial structure and biological activity of each domain.

\footnotetext{
*Correspondence: sunlk@jlu.edu.cn; sdj@jlu.edu.cn

1 Department of Pathophysiology, College of Basic Medical Sciences, Jilin University, Changchun 130021, China

${ }^{2}$ Department of Biomedicine, Regeneration Medicine Institute,

College of Pharmacy, Jilin University, Changchun 130021, China
}

Onconase is an immunotoxin with a molecular weight of $12 \mathrm{kDa}$ and consisting 104 amino acids [8, 9]. It was purified from the embryos of the Northern leopard frog (Rana pipiens), and belongs to the bovine pancreatic ribonuclease A (RNase A) superfamily [8]. Onconase has specific structural features with the presence of a Cys87Cys104 disulfide bond at the C-terminus and a pyroglutamic acid residue (Gln) at the $\mathrm{N}$-terminus [10-12]. While a methionine was present in the natural Onconase as the first amino acid, the genetically engineered version lacks the first methionine and has only $1 \%$ the activity of native Onconase. Stability of the Onconase tertiary structure is maintained by three disulfide bonds, which makes it resistance to hydrolysis by proteases and heat. In vivo and in vitro studies have shown that Onconase is cytotoxic to malignant mesothelioma and other malignant tumors including breast, pancreatic, and non-small cell lung cancers. Onconase also showed synergistic effect 
with many other chemical, synthetic, and cytokines used as anti-cancer drugs [13-17].

Recombinant Onconase has progressed to phase III clinical trials in patients with unresectable mesothelioma, and has become the first RNase to be assessed as an anti-tumor drug. In long-term clinical applications, Onconase presented the following advantages: less drug resistance, lower allergenic, lower immunogenic, and fewer side effects $[13,14]$. However, the poor capacity of Onconase to target most tumor cells has limited further clinical development.

Most tumor types overexpress a cell surface receptor termed, chemokine receptor (CXCR), which is an integral membrane protein that specifically binds and responds to cytokines of the CXC chemokine family [1820]. It represents a large family of $G$ protein-linked receptors that contain seven transmembrane proteins. There are seven CXC chemokine receptors in mammals, named CXCR1-CXCR7.

CXCR4 (fusin) serves as the receptor for a chemokine known as SDF-1 (or CXCL12) [20, 21], and is used by HIV-1 to gain entry into target cells [22, 23]. This receptor is widely distributed in cells and is expressed on most immature and mature hematopoietic cell types. Besides, CXCR4 is also overexpressed in more than 20 types of cancers, including melanoma, glioma, acute myelogenous leukemia, chronic lymphocytic leukemia, breast, prostate, renal, pancreatic, ovarian, cervical, colon, and smallcell lung cancers [18]. Since V3 was the core sequence of SDF-1 it had a potential use in drug design to target cancer cells.

In our previous study, we constructed a tumor-activated conjugate ONC-V3 and expressed it in the yeast [24], Pichia pastoris. Optimizing growth and induction conditions resulted in ONC-V3 expression reaching a maximum of $160 \mathrm{mg} / \mathrm{L}$ with a purity of $95 \%$ [24]. ONCV3 had a low hemolytic activity, which made intravenous drug delivery possible. It showed low cytotoxicity on HEK-293 cells and strong cytotoxicity on some cancer cells.

In this study, we investigated the cytotoxicity of ONCV3 on tumor cells and explored the likely mechanism by which ONC-V3 killed cancer cells by using DNA ladder degradation, fluorescence microscopic analysis, flow cytometry and transmission electron microscopy.

\section{Materials and methods}

\section{Cell lines and cell culture}

The cells used in our study are as follows:

1. HEK293, a human normal embryonic kidney cell.

2. MCF-7, a human breast carcinoma cell line.

3. A549, a human lung carcinoma cell line.
4. HO-8910PM, a human ovarian neoplasm cell line.

5. Hela, a human cervical carcinoma cell line.

6. HepG2, a human liver carcinoma cell line.

All cell lines were stored at $-80{ }^{\circ} \mathrm{C}$ in our laboratory in DMEM (Invitrogen Inc.) supplemented with $20 \%$ fetal bovine serum (FBS) and 10\% DMSO. Cells were cultured in DMEM with $10 \% \mathrm{FBS}, 100 \mathrm{unit} / \mathrm{mL}$ penicillin, and $100 \mu \mathrm{g} / \mathrm{mL}$ streptomycin at $37^{\circ} \mathrm{C}$ with $5 \% \mathrm{CO}_{2}$.

\section{Onc-v3}

ONC-V3 was expressed and purified as described in our previous study [24]. The culture was collected after $72 \mathrm{~h}$, and yeast cells were removed by centrifugation at $8000 \mathrm{rpm}$ for $30 \mathrm{~min}$ at $4{ }^{\circ} \mathrm{C}$. The supernatant was centrifuged in an ultracentrifuge and concentrated by ultrafiltration using the Amfore Ultrafiltration Membrane 10,000 . The concentrated recombinant immunotoxin was loaded onto a SP Sepharose Fast Flow column $(5.0 \times 20 \mathrm{~cm})$ pre-equilibrated with buffer A $(20 \mathrm{mM} \mathrm{PB}$, $\mathrm{pH}$ 7.0). The bound recombinant immunotoxin was eluted with buffer $\mathrm{B}(1 \mathrm{~mol} / \mathrm{L} \mathrm{NaCl})$. The eluted protein was mixed with buffer $\mathrm{C}(20 \mathrm{mM} \mathrm{PB}, \mathrm{pH} 7.0)$ and further loaded onto the Sephadex G-75 column $(1.6 \times 100 \mathrm{~cm})$ pre-equilibrated with the same buffer and purified protein was collected.

\section{Hemolysis assay of ONC-V3}

ONC-V3 was incubated with sheep red cells at the final concentrations of $20,40,60,80,100,120,140,160,180$, and $200 \mu \mathrm{mol} / \mathrm{L}$. Erythrocytes were added to a final concentration of $1 \%(\mathrm{v} / \mathrm{v})$. The components were gently mixed and incubated for $60 \mathrm{~min}$ at $37{ }^{\circ} \mathrm{C}$, and centrifuged. The optical density (OD) of the supernatants was measured at $545 \mathrm{~nm}$. Erythrocytes suspended in PBS served as the control for zero hemolysis (blank) and erythrocytes in 1\% Triton X-100 served as the control for $100 \%$ hemolysis. Data are presented as mean \pm SD of three independent experiments.

\section{Cytotoxicity of ONC-V3 on cell lines}

The different cell lines (MCF-7, A549, HO-8910PM, Hela, HepG2, HEK293) were seeded on 96-well plates at the density of $10^{4}$ cells per well, and incubated at $37{ }^{\circ} \mathrm{C}$ and $5 \% \mathrm{CO}_{2}$ for $24 \mathrm{~h}$. Then, serial dilutions of ONC-V3 $(0,0.05,0.1,0.2,0.4,0.8$, and $1.6 \mu \mathrm{mol} / \mathrm{L})$ were added to the cells after removing the medium. Six wells were maintained for each dose. The blank control contained the dilution medium without ONC-V3. Then, the cells were incubated at $37{ }^{\circ} \mathrm{C}$ with $5 \% \mathrm{CO}_{2}$ for $72 \mathrm{~h}$. Then, the supernatants were removed and the cells were washed with PBS ( $\mathrm{pH}$ 7.4). The cells were further incubated in medium containing $20 \mu \mathrm{L}$ MTT solution $(5 \mathrm{mg} / \mathrm{mL})$ at 
$37^{\circ} \mathrm{C}$ for $4 \mathrm{~h}$. Then, $100 \mu \mathrm{L}$ of dimethyl sulfoxide (DMSO) was added after removing the supernatant. $\mathrm{OD}_{490}$ was measured using an ELISA microplate reader. Cytotoxicity of the cancer cells was determined based on $\mathrm{IC}_{50}$.

\section{Flow cytometry measurement of apoptosis}

After treating $1 \times 10^{6}$ cells with serial dilutions of ONCV3 $(0,0.05,0.1,0.2,0.4,0.8,1.6 \mu \mathrm{mol} / \mathrm{L}$ and $3.20 \mu \mathrm{mol} / \mathrm{L})$ for $48 \mathrm{~h}$, the cells were collected and centrifuged at $1000 \mathrm{rpm}$ for $5 \mathrm{~min}$. Then, cells were washed twice with cold PBS before adding $1 \mathrm{~mL}$ buffer to resuspend the cells in each tube. Then, $5 \mu \mathrm{L}$ of Annexin V and $5 \mu \mathrm{L}$ of PI were added to each tube. After mixing thoroughly, the tubes were incubated at room temperature for $10 \mathrm{~min}$ and the stained cells were immediately analyzed by flow cytometry, and the excitation and emission wavelengths were 535 and $617 \mathrm{~nm}$.

\section{DAPI staining to show apoptosis}

HO-8910PM cells $\left(1 \times 10^{6}\right)$ were cultured on round coverslips in $35 \mathrm{~mm}$ petri dishes containing DMEM for $24 \mathrm{~h}$. Then, the medium was replaced with fresh culture medium containing ONC-V3 $(0.4 \mu \mathrm{mol} / \mathrm{L})$. After 0 and $48 \mathrm{~h}$ cells were washed with PBS and fixed in ice-cold methanol for $10 \mathrm{~min}$, followed by an additional wash with PBS. The cells were then stained with $1 \mu \mathrm{g} / \mathrm{mL}$ DAPI for $15 \mathrm{~min}$, and washed with PBS for $5 \mathrm{~min}$. All slides were finally observed through a fluorescence microscope.

\section{DNA ladder}

$1 \times 10^{7}$ HO-8910PM cells were collected after culture for $48 \mathrm{~h}$ in the medium containing serial dilutions $(0.4 \mu \mathrm{mol} / \mathrm{L})$ of ONC-V3. The apoptosis positive control group received $10 \mu \mathrm{mol} / \mathrm{L}$ cis-platinum in addition. The cells were washed three times with PBS, and then resuspended in $350 \mathrm{~mL}$ of lysis solution $(50 \mathrm{mmol}$ Tris- $\mathrm{HCl}$, $0.1 \mathrm{~mol}$ EDTA, $0.5 \% \mathrm{SDS})$ and $3.5 \mu \mathrm{L}(50 \mu \mathrm{g} / \mathrm{mL})$ Proteinase $\mathrm{K}$ and incubated in a water bath at $50{ }^{\circ} \mathrm{C}$ for $2 \mathrm{~h}$. Then, equal volume of phenol-chloroform-isoamyl alcohol (25:24:1) mixture was added and mixed. The resulting mixture was centrifuged at $10,000 \mathrm{rpm}$ for $10 \mathrm{~min}$ at $4{ }^{\circ} \mathrm{C}$. After discarding the supernatant, $1 / 10$ volumes of $5 \mathrm{~mol} / \mathrm{L} \mathrm{NaCl}$ and 2.5 volumes of ethanol were added. The mixture was centrifuged at $12,000 \mathrm{rpm}$ for $10 \mathrm{~min}$ at $4{ }^{\circ} \mathrm{C}$ and the pellet was washed with $75 \%$ ethanol and dried at room temperature. The pellet was re-suspended in $100 \mu \mathrm{L}$ of TE buffer ( $20 \mathrm{mM}$ Tris- $\mathrm{HCl}, 1 \mathrm{mM}$ EDTA, $\mathrm{pH} 8.0)$ and incubated with $2 \mu \mathrm{L}(10 \mathrm{mg} / \mathrm{mL})$ RNase for $1 \mathrm{~h}$ at $65{ }^{\circ} \mathrm{C}$ and finally tested on a $1 \%$ agarose gel by electrophoresis.

\section{Location of polypeptides in cells}

HO-8910PM cells $\left(1 \times 10^{6}\right)$ were cultured in $35 \mathrm{~mm}$ petri dishes with round coverslip on the bottom for $24 \mathrm{~h}$. The medium was replaced with fresh culture medium containing ONC-V3 $(0.4 \mu \mathrm{mol} / \mathrm{L})$ for 1 and $24 \mathrm{~h}$. Then, the cells were stained with the mitochondria dye, Mito Tracker Red CMXRos according to the manufacturer's protocol. After staining, cells were washed with fresh, pre-warmed growth medium three times and the cells were incubated at $37{ }^{\circ} \mathrm{C}$ for $15 \mathrm{~min}$ in pre-warmed growth medium containing $4 \%$ methanol. Then, cells were rinsed three times with PBS, and the slide covers were placed onto the slides and observed through a laser scanning confocal microscope.

\section{Wound healing assay}

For wound healing assays, HO-8910PM cells $\left(1 \times 10^{6}\right)$ were cultured in 6-well plates for $24 \mathrm{~h}$ to obtain a confluent monolayer. Vertical artificial scratches were made in the wells by scraping the cell monolayer along the diameter of each well using a $10 \mu \mathrm{L}$ pipette tip. Cells that separated from the monolayer were removed. Then, medium was added and cells were cultured for $12 \mathrm{~h}$ with PBS as solvent control, or ONC-V3 $(0,0.05,0.1,0.2,0.4,0.8$, $1.6 \mu \mathrm{mol} / \mathrm{L}$ and $3.20 \mu \mathrm{mol} / \mathrm{L}$ ). After 24 and $48 \mathrm{~h}$ in culture, the microscopic images of the scratched area before and after treatment were obtained and observed through a microscope at a magnification of $100 \times$.

\section{Transwell invasion assay}

The effect of Onconase on HO-8910PM cell invasion was measured using a transwell assay, and conducted in 6-well plates containing microporous $8 \mu \mathrm{mol} / \mathrm{L}$ membranes (Corning Costar, USA). The transwell membrane was coated with matrigel (BD Biosciences, USA), which was rehydrated by adding $45 \mu \mathrm{L}$ of serum-free medium and incubated for $4 \mathrm{~h}$. Cells were incubated with serial dilutions of ONC-V3 $(0,0.2,0.4,0.8$, and $1.6 \mu \mathrm{mol} / \mathrm{L})$ for $12 \mathrm{~h}$, and then $10^{5}$ cells were plated in the top chambers. Medium with serum was then loaded in the lower chambers. After incubation for $24 \mathrm{~h}$ at $37^{\circ} \mathrm{C}$ with $5 \% \mathrm{CO}_{2}$, cells on the top surface of the membrane were removed. The cells on the lower surface were fixed in 10\% paraformaldehyde for $30 \mathrm{~min}$ and stained with hematoxylin-eosin (H\&E). Invading cells from 3 random fields were counted through a light microscope at a magnification of $200 \times$.

\section{Western blotting}

Cells were cocultured with ONC-V3 $(0.4 \mu \mathrm{mol} / \mathrm{L})$ for $48 \mathrm{~h}$ and harvested. All cells were lysed with lysis buffer $[20 \mathrm{mmol} / \mathrm{L}$ Tris-Cl $(\mathrm{pH} 8.0), 137 \mathrm{mmol} / \mathrm{L} \mathrm{NaCl}$, $20 \mathrm{mmol} / \mathrm{L} \mathrm{DTT}, 1 \% \mathrm{NP}-40,2 \mathrm{mmol} / \mathrm{L}$ sodium vanadate, $100 \mu \mathrm{g} / \mathrm{mL}$ phenylmethylsulfonyl fluoride, $1 \mu \mathrm{g} /$ 


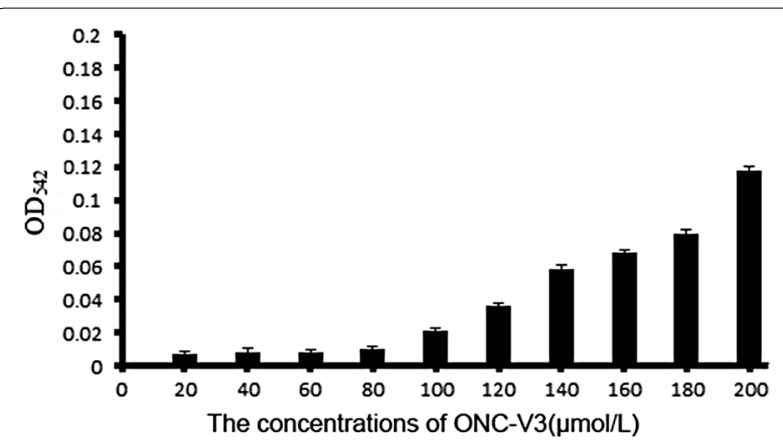

Fig. 1 The $\mathrm{OD}_{542}$ of $\mathrm{ONC}-\mathrm{V} 3$ interacts with red blood cells

Table 1 IC $_{50}$ of various tumor cells treated with Onc-V3

\begin{tabular}{lll}
\hline Cell lines & $\mathbf{I C}_{\mathbf{5 0}}$ of $\mathbf{O N C}-\mathbf{V} \mathbf{3}(\boldsymbol{\mu m o l} / \mathbf{L})$ & $\mathbf{I C}_{\mathbf{5 0}}$ of Onconase $(\boldsymbol{\mu \mathbf { m o l }} / \mathbf{L})$ \\
\hline MCF-7 & 0.36 & 0.83 \\
A549 & 0.35 & 0.71 \\
HO-8910PM & 0.38 & 0.82 \\
Hela & 0.19 & 0.57 \\
Hep G2 & 0.30 & 0.74 \\
\hline
\end{tabular}

$\mathrm{mL}$ aprotinin; $10 \mu \mathrm{L} / 10^{6}$ cells] for $40 \mathrm{~min}$ and the protein concentration was measured by using a BCA protein assay kit. Then, $20 \mu \mathrm{g}$ total protein was separated on SDS-PAGE, and transferred to a PVDF membrane (Bio-Rad, USA) for western blotting. After blocking with BSA the membrane was incubated overnight at $4{ }^{\circ} \mathrm{C}$ with antibodies against PARP $(1: 500$, ab181020, Abcam), cleaved PARP (1:500, ab32072, Abcam), procaspase 9 (1:500, ab76424, Abcam), pro-caspase 3 (1:500, ab134175, Abcam), caspase-3 (1:500, 9694, CST), or caspase- $9(1: 500,7237$, CST). The membrane was washed and further incubated with the corresponding secondary antibodies (1:2000) conjugated to horseradish peroxidase. SuperSignal ECL (Applygen Technologic, Peking, China) was used to visualize antibody binding.

\section{Results}

Hemolysis of ONC-V3

To verify the cytotoxicity of ONC-V3, an erythrocyte hemolysis assay was performed. After incubating cells with $\mathrm{ONC}-\mathrm{V} 3$ at $37^{\circ} \mathrm{C}$ for $1 \mathrm{~h}$, the $\mathrm{OD}_{542}$ was detected (Fig. 1). ONC-V3 was found to exhibit minimal hemolysis at $100 \mu \mathrm{mol} / \mathrm{L}$. This concentration is 200 times more than the $\mathrm{IC}_{50}$ concentration $(0.2-0.4 \mu \mathrm{mol} / \mathrm{L})$ estimated in cytotoxicity assays. This indicates that Onconase coupled in ONC-V3 may be safely delivered in great amounts intravenously and released after selectively recognizing tumor cells.

\section{ONC-V3 inhibited the proliferation of tumor cells but not HEK293 cells}

We expressed natural Onconase and immuno-RNase, $\mathrm{ONC}-\mathrm{V} 3$, to confirm their cytotoxic effects on cancer cells. Incubating ONC-V3 with multiple cell types for $48 \mathrm{~h}$ showed the differential effects of OVC-V3. The $\mathrm{OD}_{490}$ values are shown in Table 1. ONC-V3 effectively inhibited MCF-7, A549, HO-8910PM, Hela, and HepG2 cells at $\mathrm{IC}_{50}$ concentrations ranging from 0.19 to $0.38 \mu \mathrm{mol} / \mathrm{L}$ (Table 1). While both natural Onconase and immuno-RNase ONC-V3 inhibited the growth of selected tumor cell lines (Table 1). ONC-V3 did not inhibit the growth of HEK293 cell line (Fig. 2).

\section{ONC-V3 induced HO-8910PM cell apoptosis}

HO-8910PM cell apoptosis was then measured by flow cytometry. The cells appeared in the Q2 section, implying the occurrence of late apoptosis. Moreover, the
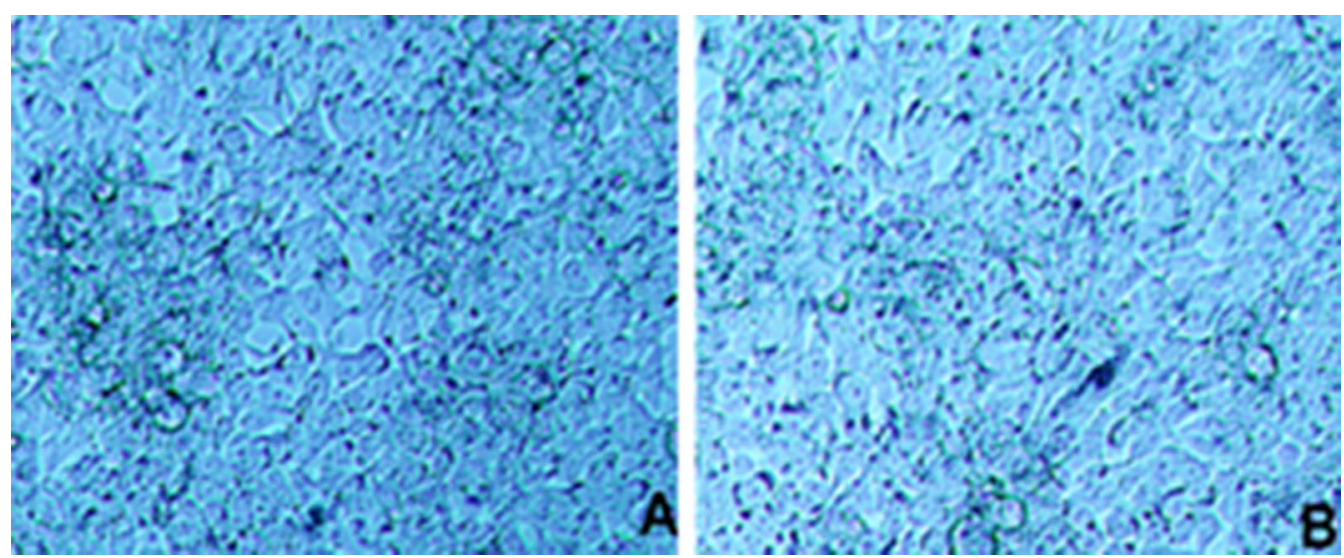

Fig. 2 HEK293 cells treated with natural Onconase and ONC-V3. A The natural Onconase, B ONC-V3 
percentage of the apoptotic cells increased in the ONCV3 dose-dependent manner (Fig. 3).

\section{ONC-V3 induced HO-8910PM cells to exhibit apoptotic morphology}

HO-8910PM cells stained with 4,6-diamidino-2-phenylindole dihydrochloride (DAPI) revealed an apoptotic morphology after culture in $0.4 \mu \mathrm{mol} / \mathrm{L} \mathrm{ONC}-\mathrm{V} 3$ for $48 \mathrm{~h}$ (Fig. 4).

\section{ONC-V3 induced apoptosis of tumor cells}

HO-8910PM cells $\left(1 \times 10^{7}\right)$ were collected after $48 \mathrm{~h}$ cul-

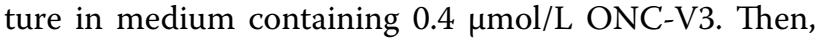
DNA was extracted and analyzed by gel electrophoresis.

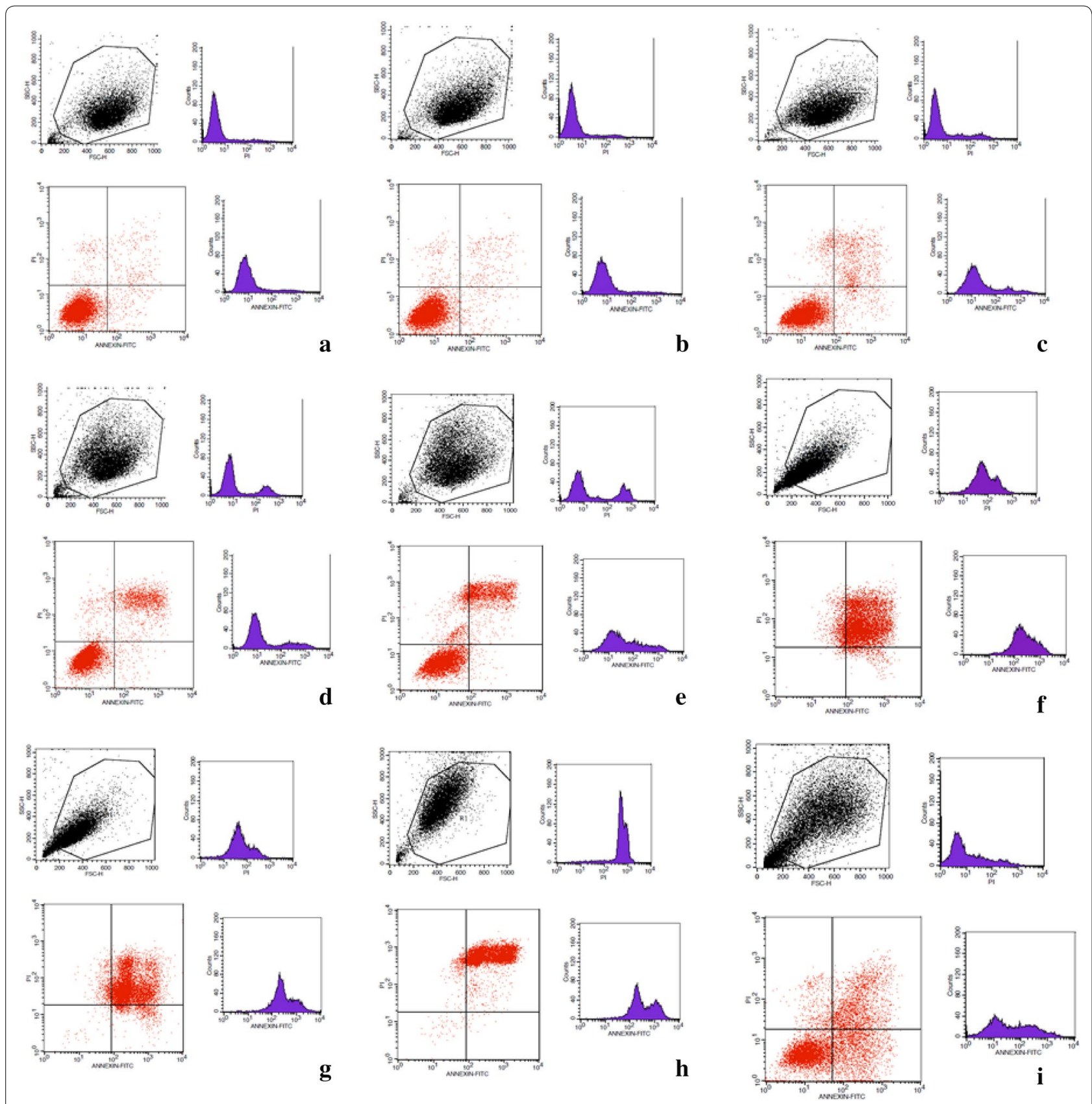

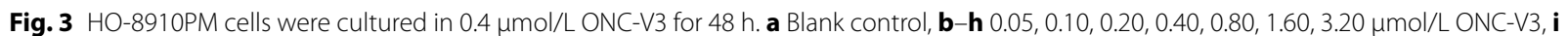
5-FU. The apoptotic cells increased along with the dose. This indicated that ONC-V3 could induce apoptosis in the cancer cells 

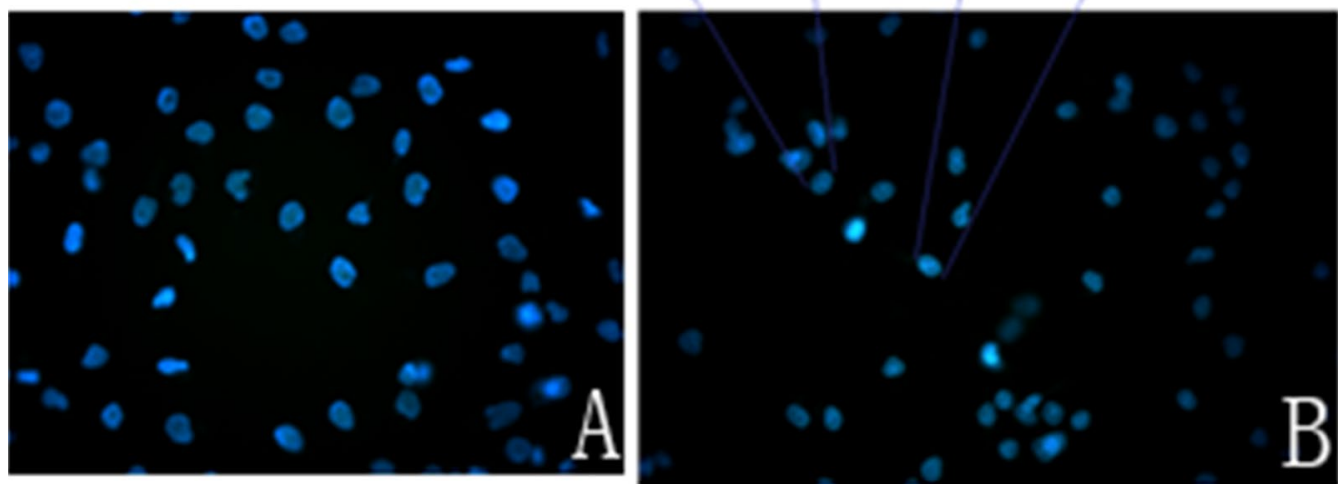

Fig. $4 \mathrm{HO}-8910 \mathrm{PM}$ cells were stained with 4,6-diamidino-2-phenylindole dihydrochloride (DAPI) after culture in $0.4 \mu \mathrm{mol} / \mathrm{L}$ ONC-V3 for $48 \mathrm{~h}$. A The blank control, B HO-8910PM cells treated with 0.4 mol/L ONC-V3. The nuclear chromatin condensed, aggregated, and decreased in volume. Some of the nuclear chromatin in the tumor cells was linear, indicating that the cells were apoptotic

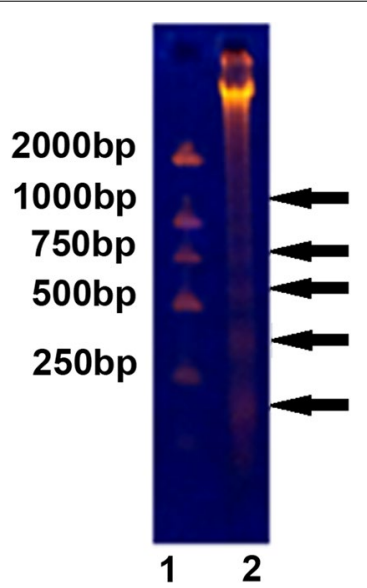

Fig. 5 Cytotoxicity to HO-8910PM cells by gel electrophoresis fluorescence of DNA after $48 \mathrm{~h}$. Lane 1: Marker; Lane 2: HO-8910PM cells with $0.4 \mu \mathrm{mol} / \mathrm{L}$ ONC-V3. The cells treated with high doses of the ONC-V3 and Melittin appear in a ladder pattern

The cells revealed a ladder pattern (Fig. 5) indicating the apoptosis appeared.

\section{ONC-V3 was distributed mainly in the cytoplasm}

ONC-V3 was labeled with fluorescein isothiocyanate (FITC) to trace its distribution in cells. When the treated cells were observed under confocal microscopy after $1 \mathrm{~h}$ of incubation, the immuno-RNase was found around the cytoplasmic membrane. With $48 \mathrm{~h}$ of incubation, it was located in the cytoplasm and subsequently. The mitochondria were stained with the mitochondria-specific Mito Tracker Red CMXRos dye as a marker in the cytoplasm (Fig. 6).

\section{ONC-V3 inhibited motility of HO-8910PM cells}

The most essential characteristics of tumor cells are invasion and metastasis. The scratch wound-healing assay was performed to analyze whether Onconase inhibits the motility of HO-8910PM cells, in vitro. After creating a wound-like gap by scratching the cell monolayer, untreated cells were found to efficiently migrate into the gap area. However, in the presence of Onconase, HO8910PM cells were significantly inhibited. When the cells were treated with $0.4 \mu \mathrm{mol} / \mathrm{L}$ ONC-V3 for $48 \mathrm{~h}$, cell motility was not affected (Fig. 7), suggesting that the Onconase effect on cell migration was not due to its cytotoxicity (Table 2).

\section{ONC-V3 suppressed migration and invasion of HO-8910PM cells}

The transwell invasion assay demonstrated a significant decrease in the migration of ONC-V3 treated cells. These findings suggested that $\mathrm{ONC}-\mathrm{V} 3$ could inhibit the migration and invasion of HO-8910PM cells (Fig. 8, Table 3). 

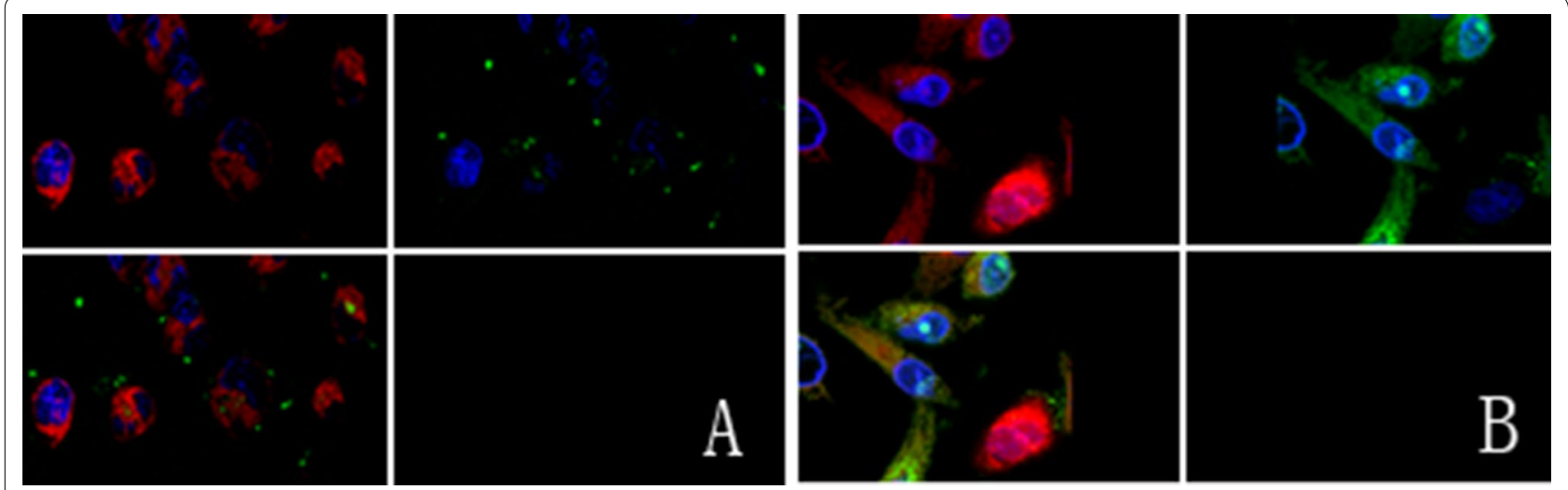

Fig. 6 The mitochondria in the cytoplasm were stained with MitoTracker ${ }^{\circledR}$ Red CMXRos red dye in the blank control group. The nucleus was stained with Hochest 33342 blue, and the red mitochondria were located in the cytoplasm surrounding the blue nucleus. A HO-8910PM cells were cultured in Onc-V3-containing medium for $1 \mathrm{~h}$. The mitochondria were shown in red and the nucleus was in blue. The green Onc-V3 protein was located on the surface of the cell. This indicated that Onc-V3 molecules can accurately target tumor cells, and a small amount of it was in the cytoplasm. B HO-8910PM cells were cultured with Onc-V3 for $48 \mathrm{~h}$. The green ONC-V3 was located in the cytoplasm together with the red mitochondria. This indicated that Onc-V3 is taken up by the tumor cells and plays a role in the induction of tumor cell apoptosis

\section{ONC-V3 suppressed migration and invasion of HO-8910PM cells}

Western blot results showed significantly decreased PARP, procaspase- 9 and procaspase-3 in Onc-V3-induced apoptosis (Fig. 9a, c). And the fragment of PARP, caspase- 9 and caspase- 3 increased (Fig. 9b, c). These suggested that Onc-V3 may induce tumor cell apoptosis via the caspase pathway, which were consistent with other reports in the literature.

\section{Discussion}

Biotherapy is currently the most popular mode of therapy to treat cancer. Immunotoxins are a kind of biotherapy that has made significant strides in cancer treatment $[6$, 7]. The ability of immunotoxins to kill cancer cells could be due to their capacity to function as antimicrotubular agents, DNA minor groove binding agents, and/or alkylating agents. Often immunotoxins are able to execute these biological activities in concentrations ranging from $\mathrm{ng} / \mathrm{kg}$ to $\mu \mathrm{g} / \mathrm{kg}$. The high cytotoxicity is an important feature to address the safety challenge of immunotoxins for systemic application in cancer patients. The improvements in toxicity of immunotoxins have accelerated the clinical development of a new generation of immunotoxins and have resulted in the recent approval of new drugs.
Another emerging problem was immunogenicity, which was elicited by many bioengineered and expressed immunotoxins after administering to cancer patients. The immune response would obviate the metabolic half-life and impose restrictions on further drug development, thus holding back their clinical use. Therefore, efforts have been made to reduce the immune response successfully.

Onconase, an RNase A like ribonuclease found in the oocytes of the Northern leopard frog, could degrade RNA and lead to cancer cells apoptosis [8-11]. In a previous study, we chose RNase like Onconase to invent a novel immuno- RNase to target CXCR4 receptors on the surface of cancer cells. We placed ONC-V3 gene downstream of the truncated Saccharomyces cerevisiae $\alpha$-mating factor-pre ( $\alpha$-MF-pre) secretion signal with the P. pastoris GAP promoter, and developed a preparation method. In this study, we were able to preliminarily detect its anti-cancer effect in vitro.

The CXCR4 chemokine receptor was overexpressed in more than 20 types of cancers, including breast cancer, ovarian cancer, glioma, pancreatic cancer, prostate cancer, AML, B-CLL, melanoma, cervical cancer, colon carcinoma, rhabdomyosarcoma, astrocytoma, small-cell lung carcinoma, CLL, renal cancer, and non-Hodgkin's 


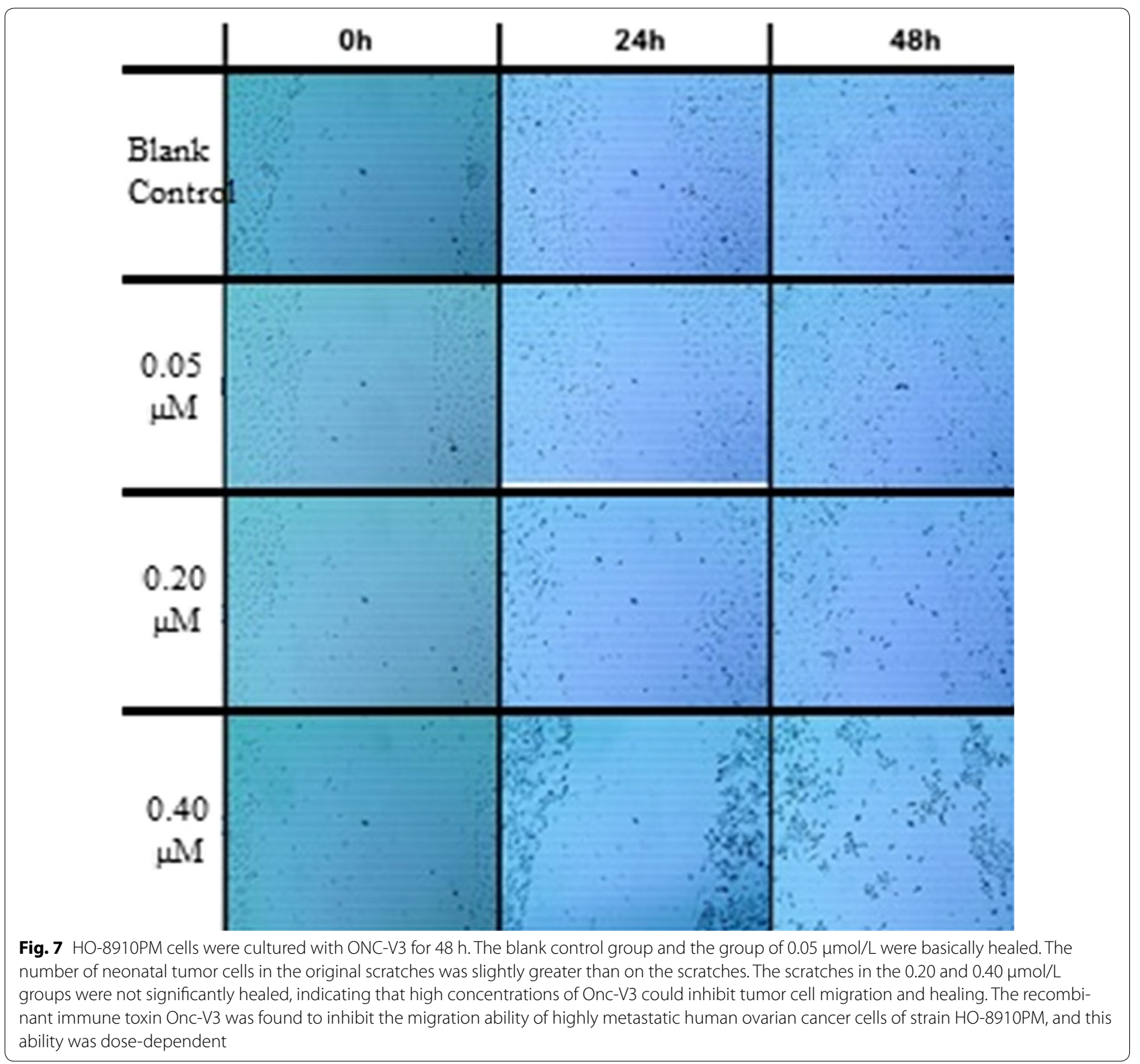

Table 2 Results of the wound healing experiments

\begin{tabular}{lllllrrl}
\hline & \multicolumn{2}{l}{$\begin{array}{l}\text { Original length } \\
(\boldsymbol{\mu} \mathrm{mol} / \mathbf{L})\end{array}$} & \multicolumn{2}{l}{$\begin{array}{l}\text { Length at } \mathbf{4 8} \mathbf{h} \\
(\boldsymbol{\mu} \mathbf{m o l} / \mathbf{L})\end{array}$} & $\begin{array}{l}\text { Healing rate } \\
(\%)\end{array}$ \\
\hline Blank control & 829 & 914 & 784 & 0 & 0 & 0 & 100 \\
0.05 & 830 & 702 & 577 & 71 & 65 & 29 & $92.39 \pm 2.27$ \\
0.10 & 714 & 815 & 572 & 94 & 108 & 78 & $86.65 \pm 0.25^{\#}$ \\
0.20 & 928 & 691 & 825 & 325 & 221 & 289 & $65.99 \pm 1.76^{\#}$ \\
0.40 & 812 & 658 & 502 & 490 & 422 & 316 & $37.52 \pm 1.94^{\#}$ \\
0.80 & 901 & 847 & 956 & 783 & 749 & 810 & $13.31 \pm 1.86^{\#}$ \\
1.60 & 793 & 933 & 960 & 740 & 892 & 923 & $4.98 \pm 1.50^{\#}$ \\
3.20 & 947 & 809 & 716 & 902 & 758 & 679 & $5.41 \pm 0.80^{\#}$ \\
Positive control & 812 & 762 & 892 & 352 & 315 & 411 & $56.41 \pm 2.38^{\#}$ \\
\hline
\end{tabular}

Results are expressed as mean $\pm S D$

$\# P \leq 0.001$ lymphoma [18]. Biotherapies that target CXCR4-overexpressing cancer cells may be feasible.

In this study, the results of the in vitro experiments demonstrated that the ONC-V3 conjugate improved the anti-cancer effect compared with Onconase, suggesting that V3 could help Onconase to target the cancer cells in order to significantly enhancing its cytotoxicity. Our internalization results demonstrated that most ONC-V3 was around HO-8910PM cells and that several molecules reached the cytosol after $1 \mathrm{~h}$, deducing that ONC-V3 may move immediately from endosomes into the cytosol, as reported for Onconase. The Cytochrome $\mathrm{C}$ was bind to tRNA to avoid the formation of apoptosome, while Onconase would degrades tRNA specifically. The 


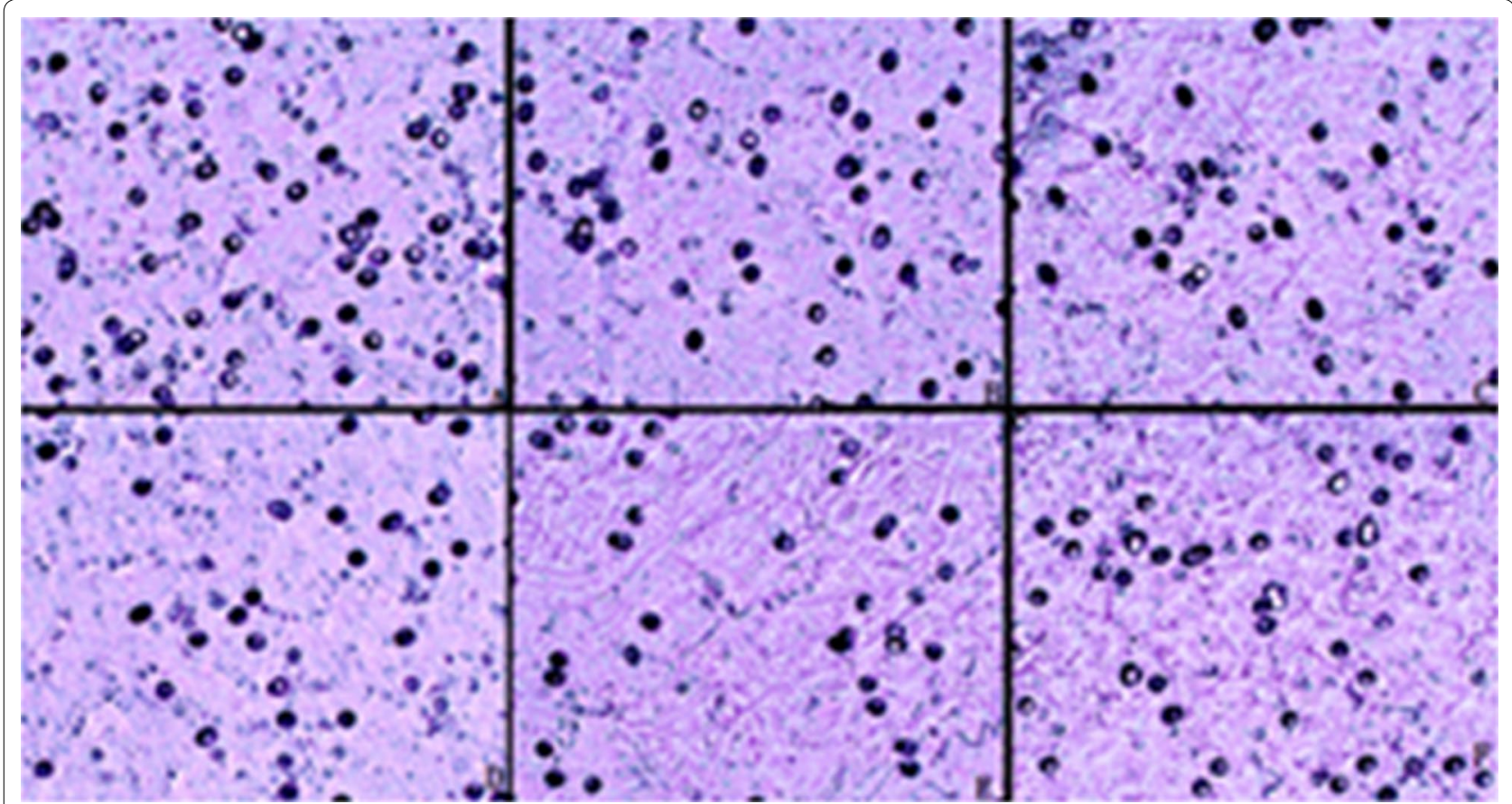

Fig. $8 \mathrm{HO}-8910 \mathrm{PM}$ cells were cultured with ONC-V3 for $48 \mathrm{~h}$. Unlike in the blank control group, the number of invasive cells penetrating the basement membrane gradually decreased as the concentration increased. The results showed the recombinant immunotoxin Onc-V3 to have an inhibitory effect on the invasion of HO-8910PM cells

Table 3 Cultivation of HO-8910PM cells with different concentrations of Onc-V3 for transwell

\begin{tabular}{ll}
\hline Onc-V3 $(\boldsymbol{\mu m o l} / \mathbf{L})$ & The number of cells \\
\hline Blank control & 201 \\
0.20 & 183 \\
0.40 & 157 \\
0.80 & 112 \\
1.60 & 74 \\
Positive control & 168 \\
\hline
\end{tabular}

Cytochrome $\mathrm{C}$ was liberated and the apoptosome was built together with Apaf-1 along the help of ATP. Then the pre-caspase 9 joined in the apoptosome and transferred to the active form caspase 9. Caspase 3 was activated by caspase 9 , so the pre-caspase 3 reduced. Along with the Cytochrome C, AIF was released from mitochondria to cytosol. It induced the degradation of nucleus, thus the PARP was cleaved and reduced. The mechanism of ONCV3 to inhibit the cancer cells was similar to the Onconase, while it increased the target ability, in other words, the cytotoxicity.

\section{Conclusion}

In this study, the constructed immunotoxin showed its good circulatory stability while it could induce the cancer cell apoptosis specifically. Therefore, the ONC-V3 conjugate designed in the present study could be used as a novel potential anticancer drug for further studies.

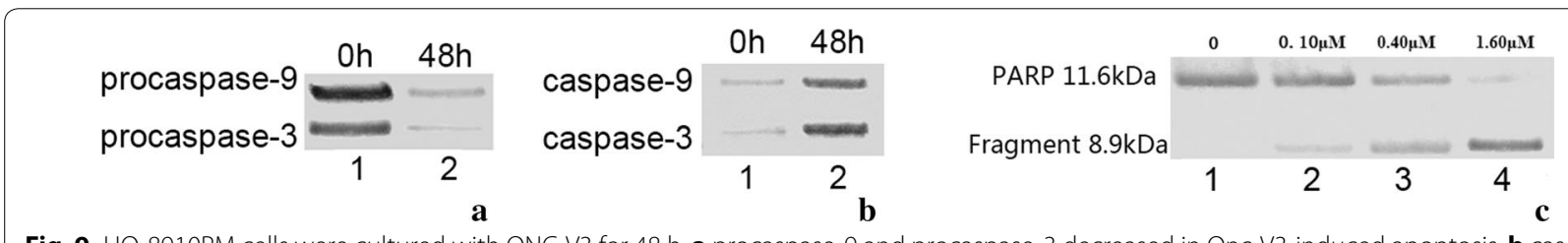

Fig. 9 HO-8910PM cells were cultured with ONC-V3 for 48 h. a procaspase-9 and procaspase-3 decreased in Onc-V3-induced apoptosis. b caspase-9 and caspase-3 increased. c PARP decreased along with the dose of ONC-V3, while the fragments of cleaved PARP increased 


\section{Abbreviations}

CXCR4: chemokine receptor 4; GIn: glutamine residue; Onc-V3: Onconase$(\mathrm{V} 3)_{2}$; RNase A: ribonuclease A; OD: optical density; FITC: fluorescein isothiocyanate.

\section{Authors' contributions}

Conceived and designed the experiments: DS and LS. Performed the experiments: MS, CZ and ML. Analyzed the data: MS, DS and LS. Contributed reagents/materials/analysis tools: MS. All authors read and approved the final manuscript.

\section{Acknowledgements}

We would like to thank LetPub (http://www.letpub.com) for its linguistic assistance during the preparation of this manuscript.

\section{Competing interests}

The authors declare that they have no competing interests.

\section{Availability of data and materials}

The datasets used and/or analysed during the current study are available from the corresponding author on reasonable request.

\section{Consent for publication}

Not applicable.

\section{Ethics approval and consent to participate}

Not applicable.

\section{Funding}

This project was supported by the cooperative construction program of Jilin Province and Jilin University (SXGJSF2017-1-2(03))

\section{Publisher's Note}

Springer Nature remains neutral with regard to jurisdictional claims in published maps and institutional affiliations.

Received: 27 September 2017 Accepted: 22 March 2018

Published online: 16 April 2018

\section{References}

1. Moertel CG. Accomplishments in surgical adjuvant therapy for large bowel cancer. Cancer. 1992;70:1364-71.

2. Harries M, Gore M. Part I: chemotherapy for epithelial ovarian cancertreatment at first diagnosis. Lancet Oncol. 2002;3:529-36.

3. Fisher B, Redmond C, Legault-Poisson S, Dimitrov NV, Brown AM, Wickerham DL, et al. Postoperative chemotherapy and tamoxifen compared with tamoxifen alone in the treatment of positive-node breast cancer patients aged 50 years and older with tumors responsive to tamoxifen: results from the National Surgical Adjuvant Breast and Bowel Project B-16. J Clin Oncol. 1990:8:1005-18.

4. Voltz Emilie, Gronemeyer Hinrich. A new era of cancer therapy: cancer cell targeted therapies are coming of age. Int J Biochem Cell B. 2008;40:1-8.

5. Jaracz Stanislav, Chen Jin, Larisa VK, et al. Recent advances in tumor-targeting anticancer drug conjugate. Bioorg Med Chem Le. 2005;13:5043-54

6. Kim JA. Targeted therapies for the treatment of cancer. Am J Surg. 2003;186:264-8.

7. Kompella UB, Lee VHL. Delivery systems for penetration enhancement of peptide and protein drugs: design considerations. Adv Drug Deliv Rev. 2001:46:211-45.

8. Darzynkiewicz Z, Carter SP, Mikulski SM, Ardelt WJ, Shogen K. Cytostatic and cytotoxic effects of Pannon (P-30 protein), a novel anticancer agent. Cell Tissue Kinet. 1988;21:169-82.

9. Mikulski SM, Ardelt W, Shogen K, Bernstein EH, Menduke H. Striking increase of survival of mice bearing Ml09 Madison carcinoma treated with a novel protein from amphibian embryos. J Natl Cancer Inst. 1990;82:151-2.
10. Ardeh W, Mikulski SM, Shogen K. Amino acid sequence of an anti-tumor protein from Rana pipiens oocytes and early embryos. Homology to pancreatic ribonucleases. J Biol Chem. 1991;266:245-51.

11. Newton DL, Walbridge S, Mikulski SM, Ardelt W, Shogen K, Ackerman AJ, et al. Toxicity of an antitumor ribonuclease to Purkinje neurons. J Neurosci. 1994;14:538-44.

12. Mikulski S, Chun H, Mittelman A, Panella T, Puccio C, Shogen K, et al. Relationship between response rate and median survival in patients with advanced nonsmall cell lung-cancer-comparison of onconase (r) with other anticancer agents. Int J Oncol. 1995;6:889-97.

13. Mikulski S, Grossman A, Carter P, Shogen K, Cosanzi J. Phase-I human clinical-trial of onconase(r) ( $p$-30 protein) administered intravenously on a weekly schedule in cancer-patients with solid tumors. Int J Oncol. 1993:3:57-64.

14. Vogelzang NJ, Aklilu M, Stadler WM, Dumas MC, Mikulski SM. A phase II trial of weekly intravenous ranpirnase (Onconase), a novel ribonuclease in patients with metastatic kidney cancer. Invest New Drug. 2001;19:255-60.

15. Rybak SM, Pearson JW, Fogler WE, Volker K, Spence SE, Newton DL, et al. Enhancement of vincristine cytotoxicity in drugresistant cells by simultaneous treatment with Onconase, an antitumor ribonuclease. J Nat Cancer Inst. 1996;88:747-53.

16. Iordanov MS, Ryabinina OP, Wong J, Dinh TH, Newton DL, Rybak SM, et al. Molecular determinants of apoptosis induced by the cytotoxic ribonuclease onconase: evidence for cytotoxic mechanisms different from inhibition of protein synthesis. Cancer Res. 2000;60:1983-94.

17. Lee I, Lee YH, Mikulski SM, Lee J, Concone K, Shogen K. Tumoricidal effects of onconase on various tumors. J Surg Oncol. 2000;73:164-71.

18. Campbell DJ, Kim CH, Butcher EC. Chemokines in the systemic organization of immunity. Immunol Rev. 2003;195:58-71.

19. Moore MA. The role of chemoattraction in cancer metastases. BioEssays. 2001;23:674-6.

20. Phillips RJ, Burdick MD, Lutz M, Belperio JA, Keane MP, Strieter RM. The stromal derived factor-1/CXC12-CXC chemokine receptor 4 biological axis in non-small cell lung cancer metastases. Am J Respir Crit Care Med. 2003; 167:1676-86.

21. Snyder EL, Meade BR, Saenz CC, Dowdy SF. Treatment of terminal peritoneal carcinomatosis by a transducible p53-activating peptide. PLoS Biol. 2004;2:186-93.

22. Zhou N, Luo Z, Luo J, Fan X, Cayabyab M, Hiraoka M, Liu D, et al. Exploring the stereospecificity of CXCR4-peptide recognition and inhibiting HIV-1 entry with D-peptides derived from chemokines. J Biol Chem. 2002:277:17476-85.

23. Oberlin E, Amara A, Bachelerie F, Bessia C, Virelizier JL, Arenzana-Seisdedos F, et al. The CXC chemokine SDF-1 is the ligand for LESTR/fusin and prevents infection by T-cell-line-adapted HIV-1. Nature. 1996;382:833-5.

24. Sun M, Tang H, Gao Y, Dai X, Yuan Y, Zhang C, et al. Constitutive expression and anticancer potency of a novel immunotoxin onconase-DV3. Oncol Rep. 2016:35:1987-94.

Ready to submit your research? Choose BMC and benefit from

- fast, convenient online submission

- thorough peer review by experienced researchers in your field

- rapid publication on acceptance

- support for research data, including large and complex data types

- gold Open Access which fosters wider collaboration and increased citations

- maximum visibility for your research: over 100M website views per year

At BMC, research is always in progress.

Learn more biomedcentral.com/submissions 